\title{
$\mathrm{H}$ 콘도의 건설에 따른 천수만 양식장 안전성 검토.
}

\author{
한두희 ${ }^{1 *}$
}

${ }^{1}$ 청운대학교 건축공학과

\section{A Safety Study of the Fish Farm in Cheonsuman after Constructing the $\mathrm{H}$ Condominium.}

\author{
Doo Hee $\operatorname{Han}^{1 *}$ \\ ${ }^{1}$ Department of Architectural Engineering, Chungwoon University
}

\begin{abstract}
요 약 본 논문은 부남호 부근에 대형 콘도를 지을 때 콘도에서 나오는 오폐수가 천수만 가두리 양식장 등에 영향 을 미치는가에 관한 것이다. 대표적으로 $\mathrm{COD}$ 를 모사하였으며, 다른 인자는 수치에 비례하여 예측할 수 있다. 조류의 이동 경로는 평균적으로 방류지점으로부터 서쪽을 향하게 되어 이곳은 가두리 양식장이 없기 때문에 비교적 안전하 며, 바닷물이 정지한 상태를 가정하여 모의한 결과 매우 천천히 확산되는 것을 보았지만, 바람 등에 의한 흐름이 있 을 경우는 오염물질의 확산을 촉진하여 쉽게 희석되기 때문에 오염물질에 의한 피해의 위험은 크지 않을 것으로 판 단된다.
\end{abstract}

\begin{abstract}
We studied sea water pollution by waste water of $\mathrm{H}$ condominium near the Bunam Lake in Seosan City. We simulated COD of discharged waste water, and other factors can be expected by proportional. The direction of sea flow is almost west, and there is no fish cultivation in the west area, so it is safe for fish cultivation. We assumed that there is no flow in the sea water, and simulated the divergence of water pollution. We concluded that, the fish cultivation will be free from danger of water pollution.
\end{abstract}

Key Words : Water pollution, Water environment, Simulation

\section{1. 서론}

충남 서산시 부남호 서남쪽에 2598명을 수용할 수 있 는 대형 콘도를 지을 경우 콘도에서 나오는 오페수가 천 수만 가두리 양식장 등에 영향을 미치는가를 예측하였다. Fig. 4에 콘도, 오폐수 방류구 및 가두리 양식장의 위치를 표시하였다. 콘도를 운영할 때 생활오수의 발생량은 「건 축물의 용도별 오수발생량 및 단독정화조 처리대상인원 산정방법(환경부고시 제2001-168호, 2001. 11. 20)」에 제시된 오수발생 원단위를 적용하였으며, 이용객은 숙박

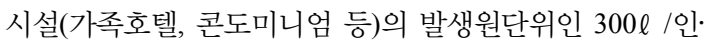
$\mathrm{m}^{2}$ 을 적용하여 휴양관광단지 운영시 이용하는 계획인원 을 기준으로 오수량을 산정하면 총 약 $779.40 \mathrm{~m}^{3} /$ 일이 발 생할 것으로 예측된다. 운영시 발생하는 오수는 계획지구
내 자체 오수정화시설을 설치하여 방류수 수질기준 이내 로 처리후 방류할 계획이며, 운영시 발생되는 오수량은 $780 \mathrm{~m}^{3} /$ 일로 계획하였다. 오수처리시설은 반응폭기공법을 사용하여 주차장 인근 지하에 설치하며 방류 농도는 $\mathrm{H}$ 콘 도와의 협의 기준으로 $\mathrm{COD} 8 \mathrm{mg} / \ell$ 또는 $5 \mathrm{mg} / \ell$ 로 해양으 로 방류할 계획이다.

\section{2. 확산 모의에 있어서 연안 해안 물리학적 이해}

연안에서 유체 요소에 작용하는 힘으로는 압력, 중력, 마찰력, 코리오리힘, 기조력, 밀도차에 의한 힘, 바람에 의한 힘 등을 들 수 있다. 이것을 식(2.1)과 같이 쓸 수 있다.

이 논문은 2010년도 청운대학교학술연구조성비의 지원에 의하여 이루어졌습니다.

"Corresponding Author: Doo Hee Han(Chungwoon Univ.)

Tel: +82-10-9352-5404 email: hanknu@hanmail.net

Received May 7, 2013 Revised (1st May 30, 2013, 2nd July 1, 2013, 3rd July 25, 2013)

Accepted August 7, 2013 


$$
\frac{\overrightarrow{d v}}{d t}=\frac{1}{\rho} \nabla p+\vec{K} \nabla^{2} \vec{v}-2 \vec{\Omega} \times \vec{v}+\vec{g}+\vec{F}
$$

이때 $\mathrm{\rho}$ 는 해수의 밀도, $\vec{\Omega}$ 는 지구 자전 각속도, $\vec{g}$ 는 중력 가속도, $\mathrm{p}$ 는 압력, $\vec{K}$ 는 운동확산계수, $\vec{F}$ 는 기타 유체 요소에 작용하는 힘이다.

\section{1 해류의 영향}

부남호 앞바다는 황해와 연결은 되어 있지만 안면도가 가로 막혀 있어 해류의 영향을 줄여주고 있다. 황해의 해 류를 부표를 이동시켜 알아본 결과 Fig. 1과 같은 형태를 보인다. 이 형태는 규칙성을 부여하기는 부족하지만 중국 과 한반도 및 대만을 연결하는 해역의 해류를 대강 분석 할 수 있는데, 외해에서 흘러 들어온 바닷물이 태안 반도 부근에서는 북쪽을 향한 것을 볼 수 있다. Fig. 2는 황해 지역의 조류타원을 나타내며 태안반도 앞은 남북 방향으 로 약 $150 \mathrm{~cm} / \mathrm{s}$, 동서방향으로 $50 \mathrm{~cm} / \mathrm{s}$ 의 운동 반경을 가지 는 경향을 보여준다. 황해의 중앙 해류는 북향하다가 랴 오뚱 반도에서 중국 서안을 따라 분산 및 약화되어 내려 오는 형태를 가지며 따라서 태안반도 앞바다의 흐름은 Fig. 2에서 보듯이 북향하나 천수만 부근은 안변도 방향 의 좁은 수로를 통하여 조류타원의 단축방향이 영향을 미칠 것으로 판단된다. 한편 부남호 앞바다의 수위가 매 우 얕으므로 원양 해류의 영향은 미미할 것으로 추정된 다. Fig. 3은 천수만 부근의 해류의 형태를 모식도로 나타 낸 것이다. 수심도에 의하면 전체적으로 볼 때 만내는 만 구보다 수심이 더 깊으며, 만구에서 만내로 향해 가면서 $\mathrm{V}$ 곡이나 $\mathrm{U}$ 곡이 아니라 조수 하천의 하류 하천 횡단면에 서 일반적으로 형성되는 $\mathrm{W}$ 자의 만저로 되어 있다.

죽도와 홍성군의 해안 사이의 해저는 밀물길이고, 죽 도와 안면도 사이의 해저는 썰물길로 나타난다. 이러한 수로가 있음은 그 연변의 해안 지형과 해협의 형태 그리 고 모래파의 형태를 보아도 알 수 있다.

천수만의 조류는 서산시 입구의 간척지 근처에서 크게 방향을 바꾸어 부석면 동쪽 연안의 썰물길을 따라서 남 향하여 안면도와 죽도 사이의 수로를 통과하여 서해로 유출되는 경향을 보인다. 이렇게 유출되는 썰물은 조류 방향의 변경 이후 상당한 시간 적돌만으로 들어오는 밀 물에 의하여 제지를 받게 되는데 이때 밀물과 썰물의 혼 합으로 간월도 부근에서 와류 현상이 강하게 일어나며, 이 와류는 간월도 남쪽에 완만한 와지를 형성하는데, 이 것이 천수만에서 입구보다 안쪽이 더 깊은 수심을 갖는 원인의 하나가 된다.

\section{Daily Mean Currents from drifters (1986-1998)}

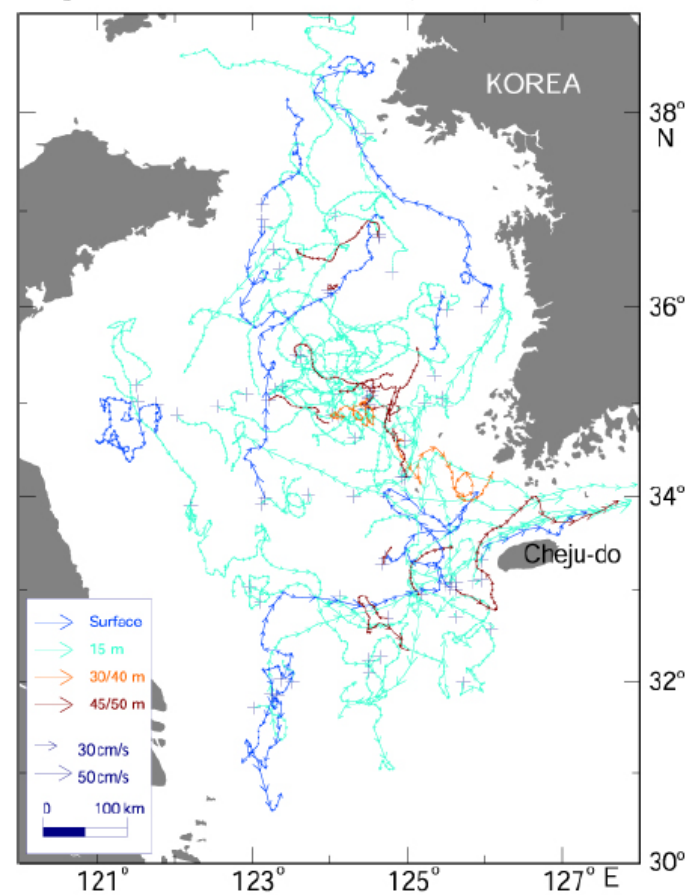

[Fig. 1] Daily averge sea flow of west sea

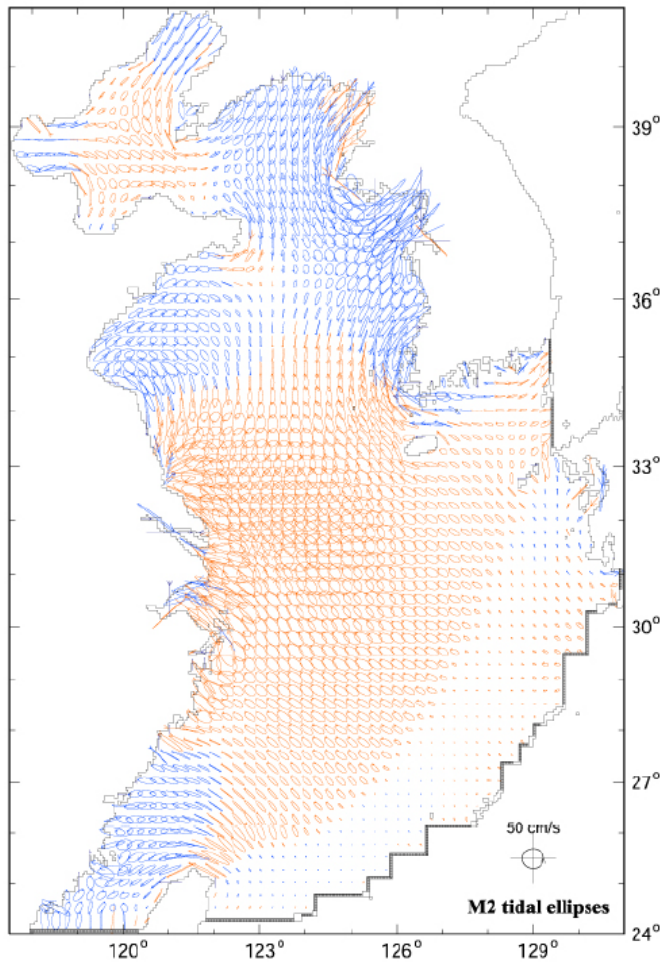

[Fig. 2] Tide ellipse of west sea 


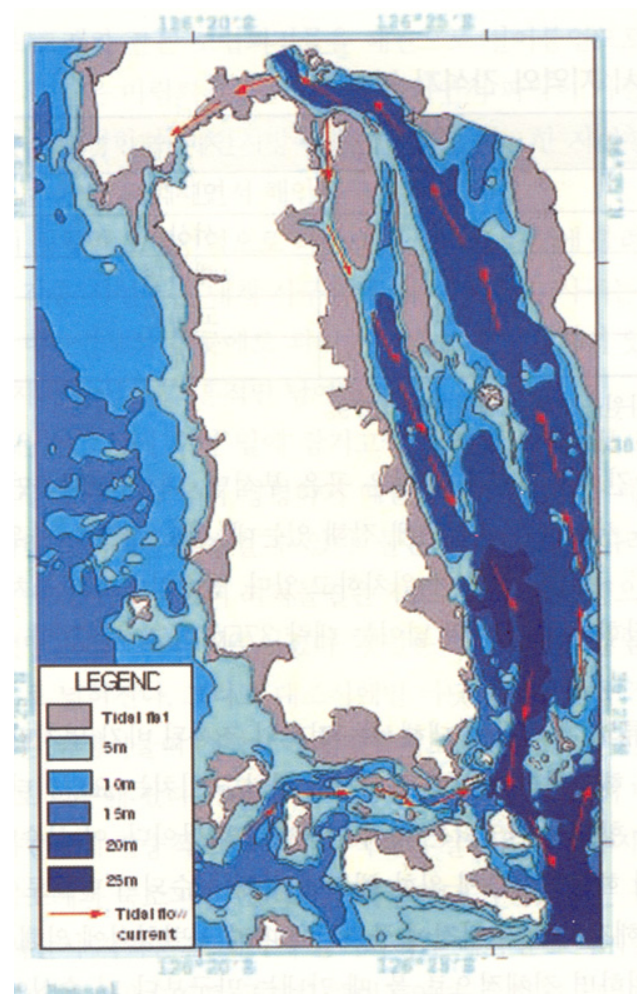

[Fig. 3] The map of sea depth and tide

\section{2 만조 및 간조의 영향}

고려하는 지형의 왼쪽은 얕고 서쪽으로 긴 형태를 가 지고 있고, 오른 쪽으로는 부남호 앞의 수심 $10 \mathrm{~m}$ 이상의 깊은 곳이 천수만을 따라 길게 남쪽으로 형성되어 있다. 만조시간에는 수위가 높아지면서 서해 방향으로 해류가 만들어질 것이며, 간조시간에는 수위가 낮아지면서 천수 만 방향으로 해류가 형성될 것이다. 천수만의 조차는 대 조차가 $6.2 \mathrm{~m}$, 소조차가 $2.8 \mathrm{~m}$ 에 달한다.

\section{3 바람에 의한 취송류}

낮에는 바닷물에 비하여 육지가 빨리 더워지므로 해풍 이 불고 밤에는 육지가 빨리 식기 때문에 육풍이 분다. 방류 예정지역은 좌우로 물길이 나 있기 때문에 새벽 및 저녁 시간을 제외하면 해풍이나 육풍의 영향을 잘 받을 수 있다. 바람은 해양의 표층을 따라 불면서 표층해류와 파랑을 발생시키며, 풍속의 $3.5 \%$ 유속을 가지는 취송류 가 발생한다. 한편 서산 지방의 풍속은 일년에 걸쳐 큰 변화를 나타내지 않으며, 대략 $2 \mathrm{~m} / \mathrm{s}$ 의 분포를 보인다. 4 월은 $2.8 \mathrm{~m} / \mathrm{s}$ 로 가장 강한 풍속을, 10 월은 약 $1.8 \mathrm{~m} / \mathrm{s}$ 로 가 장 약한 풍속을 보인다. 서산 지방의 풍계는 여름철에 남 풍 또는 남서풍 계열의 바람이, 겨울철에 북풍 계열의 바
람이 지배적이다.

\section{4 민물과 바닷물간의 밀도류}

연안해역에서의 바닷물의 밀도는 $1,020-1,028 \mathrm{~kg} / \mathrm{m}^{3}$ 정도로 민물에 비하여 높기 때문에 하천수가 바다로 유 출될 경우 해수와 담수간의 밀도차로 인한 부력효과로 방사상으로 퍼져나가는 현상이 생긴다. 수온, 염분은 다 르지만 밀도가 거의 같은 해수가 접하는 연안해역 중앙 부에는 caballing effect에 의해 고밀도의 해수가 생성되어 연직순환류를 강화시키지만 부남호 앞바다는 수심이 낮 기 때문에 그 효과는 미미하다.

\section{3. 확산 모의}

\section{1 천해방정식과 연속방정식}

얕은 바다는 해수밀도 $\rho$ 가 일정한 2 차원유체로 가정 할 수 있으며, 유속의 수평성분(u, v)는 수직방향에 무관 하다고 본다. 바닷물은 비압축성 유체로 가정하며, 운동 스케일의 가로세로비는 매우 작다고 가정한다. 현상을 지 배하는 운동방정식은 천해방정식과 연속방정식으로 다음 과 같다.

$\frac{\partial U}{\partial t}+\frac{\partial(u U)}{\partial x}+\frac{\partial(u V)}{\partial y}-f V=-g H \frac{\partial \eta}{\partial x}+\frac{\tau^{x}}{\rho}-F^{x}+T^{x}$

$\frac{\partial V}{\partial t}+\frac{\partial(v U)}{\partial x}+\frac{\partial(v V)}{\partial y}+f U=-g H \frac{\partial \eta}{\partial y}+\frac{\tau^{y}}{\rho}-F^{y}+T^{y}$

연속방정식

$$
\frac{\partial \eta}{\partial t}+\frac{\partial U}{\partial x}+\frac{\partial V}{\partial y}=0
$$

여기서 $\eta$ 는 기준해면으로부터의 변위, $h$ 는 편균해면 에서 해저까지의 수심, $H$ 는 수심 $\left(H=n+h+h_{b}\right), h_{b}$ 는 해 저의 변위, $g$ 는 중력가속도이다. $\tau^{x}, \tau^{y}$ 는 바람 응력의 $x$, $y$ 성분, $U, V$ 는 $u, v$ 를 해면에서 해저까지 적분한 것이다. $\mathrm{F}^{\mathrm{x}}, \mathrm{F}^{\mathrm{y}}$ 는 해저 마찰력의 $x, y$ 성분이며, $T^{x}, T^{y}$ 는 수평점성 력의 $x, y$ 방향의 성분이다.

\section{2 모의 시나리오}

천수만 부근의 지형에 의한 조류의 경향은 현재 방류 구의 위치가 양식장의 피해를 줄일 수 있는 위치임을 보 
여 준다. 또한 바람에 희한 취송류도 바람의 방향이 연중 변화하므로 양식장에 피해를 줄 수 있는 서풍의 확률은 주야로 변하는 해륙풍의 변화를 제외하면 적다고 할 수 있다. 서풍의 영향을 $2.5 \mathrm{~m} / \mathrm{s}$ 하면 해수 표면 유속은 $8.8 \mathrm{~cm} / \mathrm{s}$ 이며 따라서 이러한 취송류의 영향을 받을 때와 해수가 정지하였을 때로 구별하여 모의하였다. 해저 데이 터는 해도(DC322)와 수심도를 참고하였으며 방류구 위 치는 현대콘도 오수처리계획도를 참고하였고, 현재 설치 된 방류구의 위치를 사용하였다. 현재도 $0.2-1 \mathrm{cms}$ 정도로 방류되고 있으며, 향후 예상되는 현대콘도의 방류량 $9.3 \times 10^{-3} \mathrm{cms}$ 는 극히 일부의 방류량으로 추산된다. Fig. 4 는 콘도예정지, 방류구 및 가두리양식장의 현재 및 이설 위치를, Fig. 5는 방류구를 보여준다.

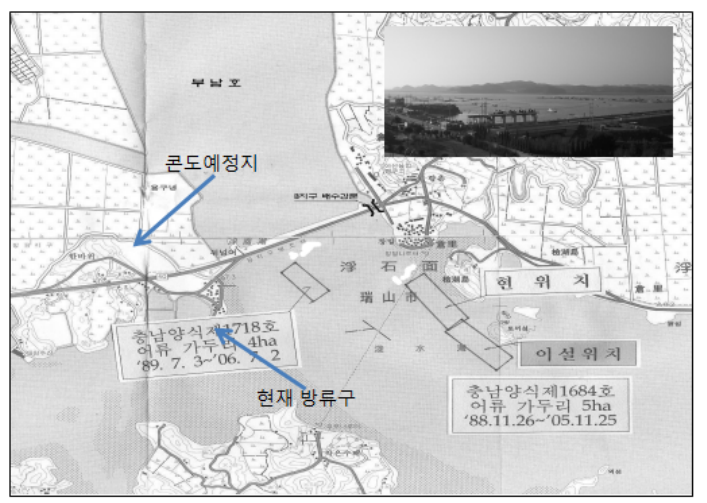

[Fig. 4] Nursaries around Bunam lake

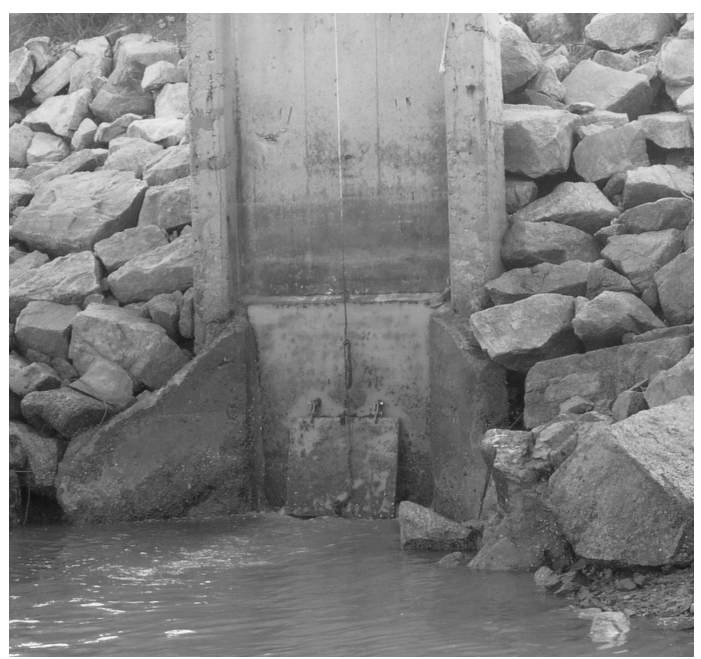

[Fig. 5] Present discharge gate

Fig. 6과 Fig. 7은 현재 방류구 부근의 해저지형을 토 대로 수심이 낮아졌을 때를 기준으로 작성한 지형의 메
쉬를 나타내 준다. 이 지형을 이용하여 서풍의 영향을 받 아 동쪽으로 해류가 형성되는 악조건에서와 정지된 바다 에 대하여 모의하였다. 바닷물의 비중은 1.03 을 사용하였 고, 밀도차에 의하여 방류수가 바닷물에 뜰 것을 예상하 여 바람의 영향을 직접 받을 때를 모의하였다.

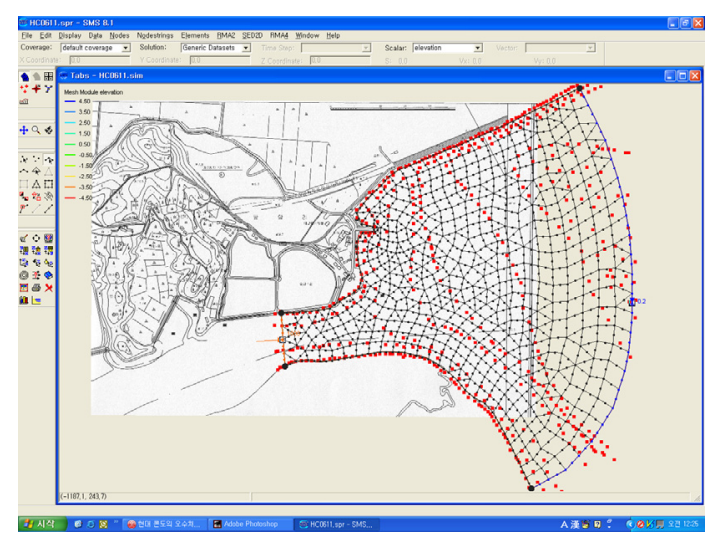

[Fig. 6] Mesh map around discharge gate

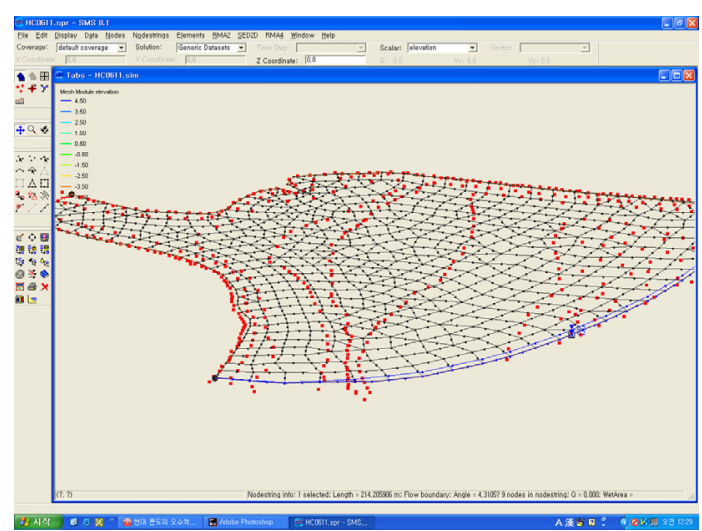

[Fig. 7] Mesh map around discharge gate (3dim)

모의는 SMS8.1을 사용하였고, 방류구를 통하여 방류 된 오염물질의 확산의 물리적 확산을 모의하기 위해서 GFGEN, RMA2 및 RMA4 모형을 적용하였다[1-5].

\section{3 부남호 앞바다가 정지하였을 때의 유속 모의}

이것은 바람의 영향, 조류의 영향 등을 생략한 모의이 며, 이 경우 유속은 방류구를 빠져 나오는 $1 \mathrm{cms}$ 의 방류수 를 가정하였다. RMA2 모의를 위해 요구되는 입력계수 로 난류확산계수(eddy viscosity)와 Manning값을 들 수 있다. Table 1은 USACE-WES에서 제시하고 있는 난류확 산계수 값을 나타내고 있으며, 본 모의에서는 난류확산계 
수 값으로 5,000을 사용하여 모의하였다. Table 2는 모의 하고자 하는 수체의 특성에 따른 Manning 값의 범위를 나타내고 있으며, 본 모의에서는 0.025 를 적용하였다.

Table 3 은 모의에 사용한 인자를 정리한 것이다.

[Table 1] Eddy viscosity

\begin{tabular}{|c|c|}
\hline Type of Problem & $\varepsilon$ Value $\left[\mathrm{N} \cdot \mathrm{sec} / \mathrm{m}^{2}\right]$ \\
\hline \hline $\begin{array}{c}\text { Homogenous horizontal flow around } \\
\text { an island }\end{array}$ & $500-5000$ \\
\hline $\begin{array}{c}\text { Homogenous horizontal flow at a } \\
\text { confluence }\end{array}$ & $1100-5000$ \\
\hline $\begin{array}{c}\text { Steady-state flow for thermal } \\
\text { discharge to a slow moving river }\end{array}$ & $1000-50000$ \\
\hline
\end{tabular}

[Table 2] n-value of Manning

\begin{tabular}{|c|c|}
\hline Status & $\mathrm{n}$ value \\
\hline \hline Shallow river & $0.025-0.035$ \\
\hline Deep river & $0.018-0.025$ \\
\hline Shallow river mouse & $0.020-0.030$ \\
\hline Deep river mouse & $0.015-0.020$ \\
\hline Wet land & $0.05-0.10$ \\
\hline
\end{tabular}

[Table 3] simulation factors

\begin{tabular}{|c|c|}
\hline Factors & Value \\
\hline \hline Eddy viscosity & 5000 \\
\hline n-value of Manning & 0.025 \\
\hline density of sea water & 1.03 \\
\hline
\end{tabular}

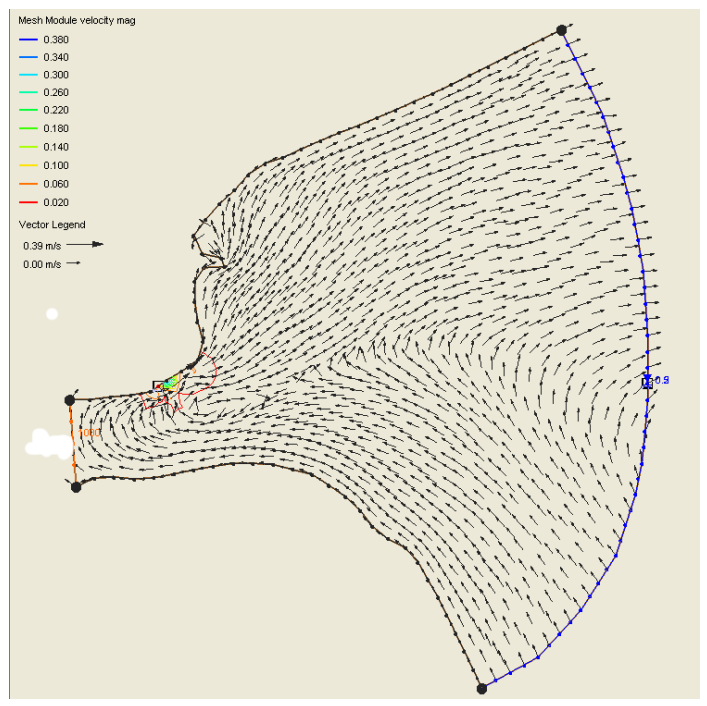

[Fig. 8] Fluid speed field of discharged water

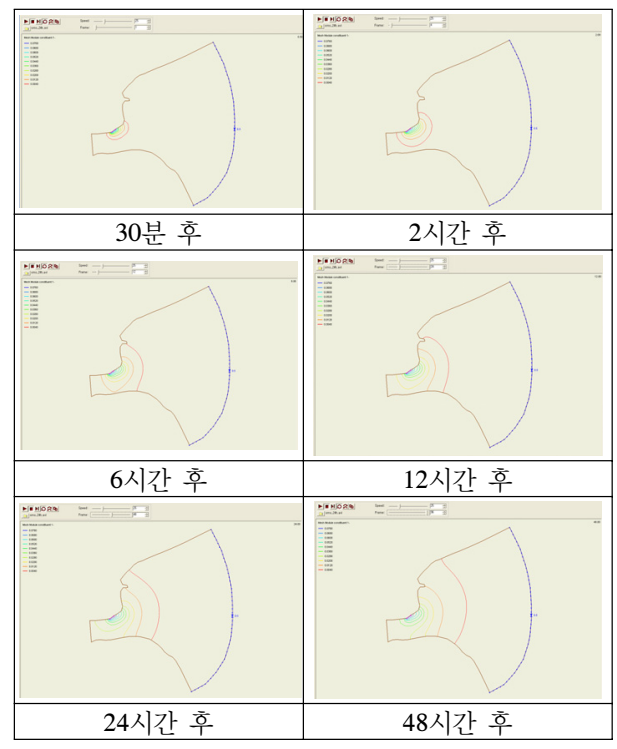

[Fig. 9] Difusion rate of discharged water. COD $8 \mathrm{mg} / 1(1 \mathrm{cms})$ by sea flow

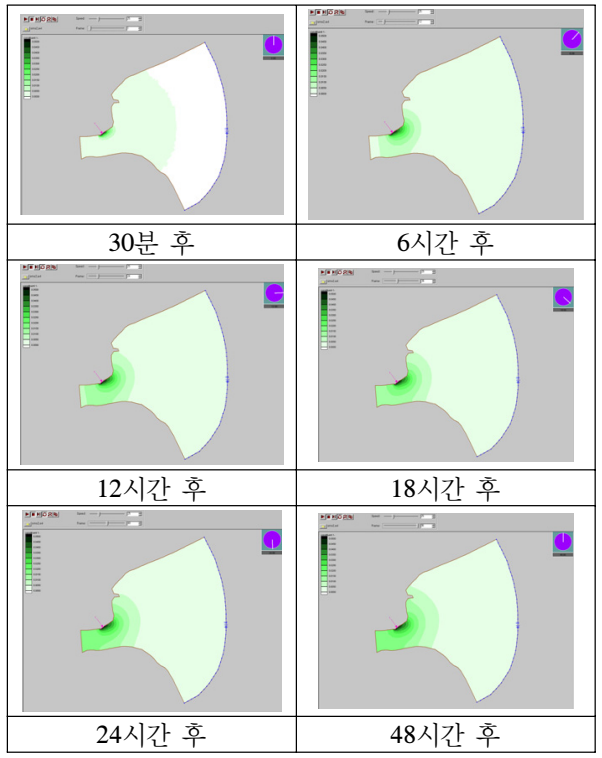

[Fig. 10] Difusion rate of discharged water. COD $5 \mathrm{mg} / 1(1 \mathrm{cms})$ by sea flow

Fig. 9와 Fig. 10의 경우 색상별 오염도는 100 을 곱하여 산정하면 되는데 그 이유는 방류량을 $1 \mathrm{cms}$ 로 잡았기 때 문에 오염물질의 농도를 100 배 희석한 값인 0.08 로 모의 했기 때문이다. $8 \mathrm{mg} / 1$ 의 경우 바깥으로부터 0.0040 , $0.0120,0.0200,0.0280,0.0360,0.0440,0.0520,0.0600$, $0.0680,0.0760$ 이다. $5 \mathrm{mg} / 1$ 의 경우도 바깥으로부터 $0.0025,0.0075,0.0125,0.0200,0.0225,0.0275,0.0325$, 
$0.0375,0.0425,0.0475$ 이며 전체적인 시간대역별 확산 정 도를 볼 수 있다.

\section{4 취송류의 극한 상황에 대한 유속 모의}

서산지역은 일년 대부분이 북동풍과 남서풍이 불어 고 려하고 있는 방류구 주면에 직접적인 영향을 주지 않는 다. 하지만 적어도 하루에 두 번씩 동서방향으로 해륙풍 이 불며, 바닷물에 비하여 방출류의 비중이 낮기 때문에 바람의 영향을 받게 된다. 서풍이 $2 \mathrm{~m} / \mathrm{s}$ 로 불면 $7 \mathrm{~cm} / \mathrm{s}$ 의 해류 표면 취송류가 생기며 이것의 $50 \%$ 강화된 $12 \mathrm{~cm} / \mathrm{s}$ 정도이 취송류가 발생할 경우를 모의하였다. Fig. 11은 서풍과 조류 등이 동쪽 해류를 형성할 경우 유속 모양을 나타내 준다. 이 경우 방류되는 오염물에 의하여 오른쪽 에 위치한 가두리 양식장에 나쁜 영향을 줄 것으로 생각 할 수 있다. 그러나 Fig. 12와 Fig. 13의 경우를 보면 이런 해류가 오염물질의 확산을 촉진하여 방류 후 30 분 이내 에 $2 \mathrm{mg} / 1$ 이하로 희석되는 것을 확인할 수 있다.

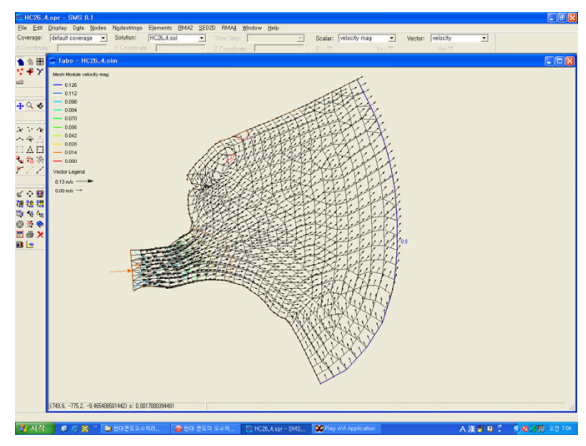

[Fig. 11] Tide simulation extreme condition

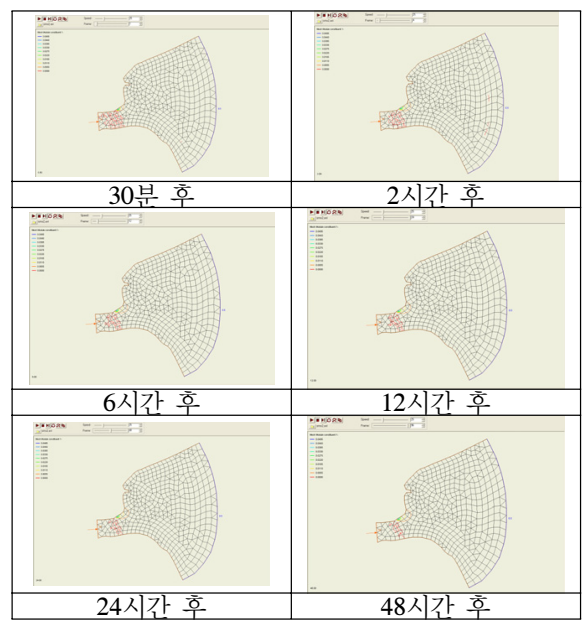

[Fig. 12] Difusion rate of discharged water. COD $8 \mathrm{mg} / 1(10 \mathrm{cms})$ by wind flow

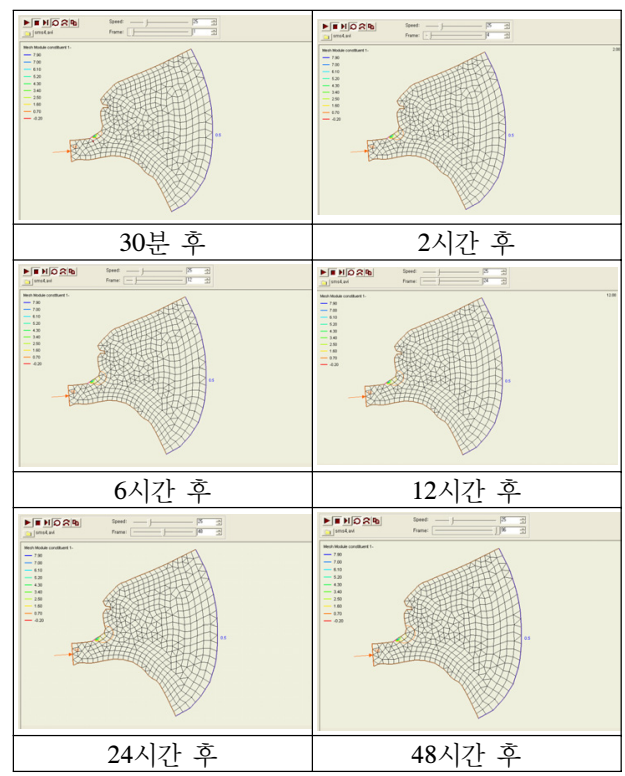

[Fig. 13] Difusion rate of discharged water. COD $5 \mathrm{mg} / 1(10 \mathrm{cms})$ by wind flow

\section{4. 결론 및 토의}

이상에서 살펴본 바와 같이 조류의 이동 경로는 평균 적으로 방류지점으로부터 서쪽을 향하게 되어 이곳은 가 두리 양식장이 없기 때문에 비교적 안전하며, 정지상태를 가정하여 모의한 결과 매우 천천히 확산되는 것을 보았 지만 실제로는 이런 경우는 바람이 전혀 없는 일부 시간 이나 썰물과 밀물이 만나는 일부 시간만이 해당될 것이 다. 또한 바람 등에 의한 흐름이 있을 경우는 오염물질의 확산을 촉진하여 쉽게 희석되기 때문에 오염물질에 의한 피해의 위험은 크지 않을 것으로 판단된다. 양식장의 경 우 $\mathrm{COD}$ 기준 $2 \mathrm{ppm}$ 이하를 요구하므로 콘도 건설 후 $\mathrm{COD} 8 \mathrm{ppm}$ 의 농도로 배출하여도 가두리 양식장은 안전 하다. 방류 위치는 현재의 위치도 무난하며, 조류의 경향 을 볼 때 외해로 방류하기 보다는 현재 보다 왼쪽 방향으 로 내는 것이 더 합리적인 선택이라 여겨진다. Fig. 14는 제안된 방류구의 위치를 보여준다. 


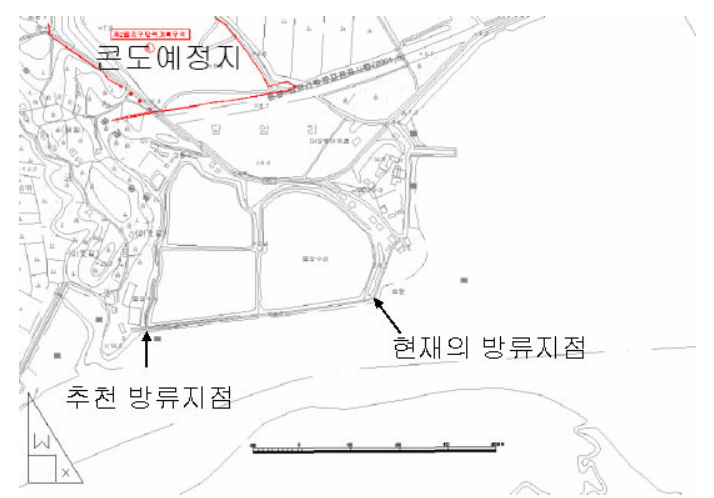

[Fig. 14] The suggested position of discharged water gate

\section{Reference}

[1] ems-i, "Two- Dimensional Hydraulic Modeling of Complex Waterways with SMS", EMS-I Training Manual, ems-i, 2005.

[2] K. Han etc., "Development and Application of 2-Dimensional Water Quality Model in the Down Stream of Han River", J. of Korea Water Resources Association, Vol. 35, 2002

[3] K. Han etc., "2-Dimensional Water Dynamic Analysis by Number Model and GIS in the River", J. of the Korean Society of Civil Engineers, Vol. 21, 2001

[4] Alam, M. M., et.al, "Collocation finite element simulation of dam-break flows", J. of Hyd. Eng., ASCE, Vol.121, 1995

DOI : http://dx.doi.org/10.1061/(ASCE)0733-9429(1995) 121:2(118)

[5] Hicks, F.E., et. al., "Characteristic dissipative Galerkin scheme for open channel flow", J. of Hyd. Eng., ASCE, Vol.118, 1992

[6] Y. Lee, D. Han etc., "Water Quality Improvement in Bunam Lake", Final Report to Hyundai Construction, Hanseo University, 2005

[7] D. Han, "Waste Water Spreading Modeling by Bunam Lake Gates", Proceedings of KAIS Fall Seminar, 2009
한 두 희(Doo Hee Han)

[종신회원]

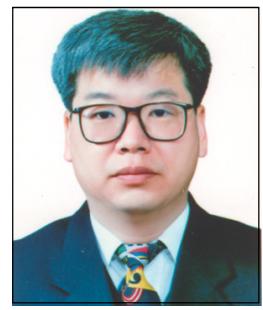

- 1994년 2월 : 경북대학교 대학원 물리학과 (이학박사)

- 1996년 8월 1999년 12월 : 한 국전자통신연구원 방문연구원

- 1996년 3월 현재 : 청운대학교 건축공학과 교수

<관심분야>

물리응용, 폐기물재활용, 신재생에너지, 열환경 